\title{
Social bullying in nursing academia: Addressing the phenomenon
}

\author{
Abigail Fuller* \\ School of Nursing, Schreiner University, Kerrville, Texas, United States
}

Received: July 27, 2019

Accepted: August 27, 2019

Online Published: September 4, 2019

DOI: $10.5430 /$ jnep.v9n11p105

URL: https://doi.org/10.5430/jnep.v9n11p105

\begin{abstract}
Social Bullying is a phenomenon that is becoming far too prevalent in nursing academia. It can steal the joy out of teaching and leave faculty feeling disrespected and marginalized. This article reviews the consequences of social bullying in nursing academia and cites the importance of nursing academia working together to find solutions to this problem.
\end{abstract}

Key Words: Social bullying, Incivility, Nursing academia

\section{INTRODUCTION}

The topic of social bullying has been gradually receiving more attention in the literature. In the United States, we use terms such as incivility, and lateral or horizontal violence. ${ }^{[1-3]}$ In other countries, such as the United Kingdom, Canada and Australia the term "Social Bullying" is used. ${ }^{[4]}$ Whatever term used to describe it, this phenomenon is far too prevalent in nursing and nursing academia. ${ }^{[4-7]}$ This behavior can be subtle such as a remark causing offense, or more obvious behavior like a deliberate act of disrespect intended to undermine one's self-esteem.

\section{BACKGROUND}

Considering the current nursing faculty shortage, it is essential that civility is cultivated among nurses in academia. Social Bullying can steal the joy out of teaching and leave faculty feeling disrespected and marginalized. ${ }^{[8]}$ When the academic leadership (those in power) protect bullies in the workplace, the abuse becomes normalized. Thus, creating a culture that can have a negative effect on faculty well-being and their recruitment and retention. ${ }^{[6]}$ Competent, energetic faculty members have been forced out or "let go" because of the negative practice of social bullying.

A qualitative study by Goldberg, et al. ${ }^{[4]}$ sought to study the phenomenon of social bullying in nursing academia. They defined social bullying "as persistent, demeaning, downgrading activities incorporating vicious words and cruel acts that undermine self-esteem" [pg.191]. The researchers identified several major themes among the participants related to social bullying such as, "Bullying Tactics/Tricks of the Trade, Targeting, Cyberbullying, and Power and Control". Furthermore, subthemes were associated with each of the major themes. For example, Bullying tactics, the most frequently identified theme, included a subtheme of withholding valuable information from new faculty and providing minimal orientation.

Another study by Peters ${ }^{[2]}$ used a Heideggerian hermeneutical phenomenological approach to investigate novice faculty's lived experiences of uncivil interactions with senior faculty. Five emotionally distressing themes emerged depict-

\footnotetext{
*Correspondence: Abigail Fuller, PhD, RN; Email: abfuller89@ outlook.com; Address: School of Nursing, Schreiner University, 2100 Memorial Dr., Kerrville, Texas 78028, United States.

Published by Sciedu Press 
ing the novice faculty's interpretation of their lived experiences with faculty-faculty incivility. They are as follows: "sensing rejection from colleagues, employing behaviors to cope with uncivil colleagues, sensing others wanted novice faculty to fail, sensing a possessiveness of territory from senior faculty, and struggling with a decision to remain in academia" [pg. 219]. In addition, the study offered insight into how faculty-faculty incivility influenced novice faculty's decision to continue to teach at the institution.

\section{Strategies to ADDRESS BUllying AND INCIVILITY}

Although it is important to identify the problem and its scope, it is equally important to identify strategies to combat the problem. A phenomenological study by Wieland and Beitz ${ }^{[6]}$ investigated resilience to social bullying in nursing academia. The findings of the study suggest that negative consequences of social bullying may be minimized or deterred by faculty using resilience strategies. The themes related to resilience identified by the researchers were "developing insight, sharing and awareness of bullying, observing other peoples' strategies, coping behaviors, and confrontation of the bully with expertise" [pg. 290]. They also found that when faculty decided to leave and seek work elsewhere, they perceived this as a positive action and looked forward to teaching in a new, positive environment.

During my years teaching in nursing academia, I have witnessed the faculty to faculty incivility phenomenon on numerous occasions. Furthermore, not only have I observed other faculty members being bullied, but I have also been the recipient of this malicious and psychologically damaging behavior. We adamantly teach our nursing students about the negative aspects of incivility, as well as horizontal and lateral violence in the workplace. We emphasize the need to not "eat our young". Yet we do not always cultivate civility among ourselves.

What then is the cause of social bullying/incivility in nursing academia? Is it in the attempt to manage the stress of the job, that energy is inappropriately directed at others who are perceived as weak? Certainly, nursing academia has its challenges, internal and external. Birks, et al. ${ }^{[9]}$ suggests the cause is the inability of faculty to handle these internal and external stressors. Whatever the cause, if we continue to ignore this problem, it will have serious consequences for our profession. We will continue to lose qualified faculty, further contributing to the nursing faculty shortage. Moreover, a culture of incivility in nursing academia undermines the teaching and learning process, affecting student learning outcomes. ${ }^{[10]}$

\section{Conclusion}

Social bullying simply does not belong in a caring profession such as nursing. Nor does it belong in a scholarly environment. The literature identifies the negative implications of workplace bullying for nursing academia. ${ }^{[4-6,8,9]}$ As a profession, we can no longer afford to tolerate a culture of bullying/incivility. It is imperative that we all work together to change the culture of nursing academia to one of positive collaboration and mutual respect. I believe that the majority of faculty in nursing academia yearn to teach in a positive, nurturing environment, where they feel valued and find joy in teaching. Now is the time for us to come together as a specialty and find solutions to end social bullying in nursing academia.

\section{CONFLICTS OF INTEREST Disclosure}

The author declares that there is no conflict of interest.

\section{REFERENCES}

[1] Becher J, Visovsky C. Horizontal violence in nursing. Medsurg Nursing. 2012; 4: 210-231.

[2] Peters AB. Faculty to faculty incivility: Experiences of novice nurse faculty in academia. Journal of Professional Nursing. 2014; 30: 213 227. PMid:24939331 https://doi.org/10.1016/j.profnurs .2013 .09 .007

[3] Gallo VJ. Incivility in nursing education: A review of the literature. Teaching and Learning in Nursing. 2012; 7: 62-66. https: //doi.org/10.1016/j.teln.2011.11.006

[4] Goldberg E, Beitz J, Wieland D, et al. Social Bullying in Academia. Nurse Educator. 2013; 38: 191-197. PMid:23969747 https : //doi . org/10.1097/NNE. 0b013e3182a0e5a0

[5] Jones L, Echevarria I, Sun E, et al. Incivility across the nursing continuum. Holistic Nursing Practice. 2016; 30: 263-268. PMid:27501208 https://doi.org/10.1097/HNP.0000000000000167

[6] Wieland D, Beitz JM. Resilience to social bullying in academia: A phenomenological study. Nurse Educator. 2015; 40: 289-293.
PMid:25950796 https://doi.org/10.1097/NNE. 0000000000 000169

[7] Clark CM, Springer PJ. Incivility in nursing education: A descriptive study of definitions and prevalence. Journal of Nursing Education. 2007; 4: 7-14.

[8] Heinrich KT. An optimist's guide for cultivating civility among academic nurses. Journal of Professional Nursing. 2010; 26: 325-331. PMid:21078500 https://doi.org/10.1016/j.profnurs. 201 0.07 .002

[9] Birks M, Budden LM, Stewart L, et al. Turning the tables: the growth of upward bullying in nursing academia. Journal of Australian Nurses. 2014; 1685-1687. PMid:24467427 https://doi .org/10.1111/ jan. 12317

[10] Muliira J, Natarajan J, van der Colff J. Nursing Faculty academic incivility: perceptions of nursing students and faculty. Bio Med Central Medical Education. 2017; 17: 253-263. PMid:29237443 https://doi.org/10.1186/s12909-017-1096-8 